\title{
CLASS AGAINST CLASS: THE FRENCH COMMUNIST PARTY AND THE COMINTERN
}

\section{A STUDY OF ELECTION TACTICS IN 1928}

Since the 1930's the French Communist party has faithfully endorsed the policy decisions of the Soviet Union, oftentimes despite disagreement with major Soviet pronouncements. ${ }^{1}$ In the 1920's, however, the French Communist leadership was divided over the appropriateness of Soviet instructions on matters that appeared to many French Communists clearly within the exclusive domain of the French party. The intrusion of the Comintern, the Soviet-dominated international Communist organization, into the pre-campaign discussion of the tactics for the 1928 elections to the French national assembly forced French Communists to re-examine their goals, their position in French politics, and their relationship with the Soviet Union. The decisions of the French party leaders, made amid what was perhaps the last animated and freewheeling public party debate, determined the party's relationship with the USSR for a full forty years.

The disagreement over election tactics originated in the concern of a Comintern official for the politics and posture of the French party. Jules Humbert-Droz, director of the Comintern's Latin Secretariat and Comintern representative to the French party congress at Lille in June 1926, was alarmed at the efforts of French Communists to reach election agreements with members of the Socialist party. ${ }^{2}$ To Humbert-

1 The French Communist party's criticism of the invasion of Czechoslovakia by the Soviet Union, Bulgaria, East Germany, Hungary, and Poland was a rare example of infidelity. See The New York Times, August 22, 1968.

${ }^{2}$ Classe contre classe, Latin Secretariat, Sixth Comintern congress, Jules Humbert-Droz, pp. 233-234. The Sixth Congress of the Communist International was held in Moscow, July 17 to September 1, 1928. Classe contre classe, la question française au IXe exécutif et au VIe congrès de l'Internationale Communiste (Paris, 1929) reproduces the discussion by the Latin Secretariat during the Sixth Comintern congress and the resolution of the Comintern executive committee on the policies of the French Communist partv.

From 1921-1931 Jules Humbert-Droz directed the Comintern's Latin Secretariat (France, Italy, Spain, Portugal, Belgium, and Latin America). After the elimination of Grigori Zinoviev from the presidency of the Comintern, 
Droz any alliance forged in the hope of capturing votes, whether on the local or national level, was unworthy of a revolutionary, proletarian party; in addition such action violated Comintern instructions. He was convinced that the French party was riddled with opportunists, who were prepared to ally with the leaders of the middle-class parties to obtain victory at the polls. ${ }^{1}$ Had not former party chief Albert Treint predicted a split in Socialist ranks which he hoped would facilitate a rapprochement between the Communist party and the center and left elements of the Socialist party ${ }^{2}$ Moreover, Communist leaders oftentimes acted more like the bourgeois politicians they condemned than like revolutionaries. The Communist leadership cancelled demonstrations under government pressure, obeyed court injunctions, invoked parliamentary immunity whenever Communist deputies were threatened with arrest, and in many cases voluntarily surrendered to the public authorities when convicted of lawbreaking. These were not revolutionary actions. ${ }^{3}$

After the party congress sessions had ended, Humbert-Droz lectured

Nikolai Bukharin served as Comintern president. Humbert-Droz was Bukharin's confidant, collaborator, and political ally and supported his opposition to Stalin; as a result, Humbert-Droz was ousted from the executive committee and secretariat of the Comintern in 1931.

1 The opportunist epithet was applied whenever Comintern or party leaders wanted to stress the revolutionary and proletarian character of the Communist parties. It is oftentimes difficult to determine which of Humbert-Droz's opinions were his own and which were the expression of Comintern policy. In September 1928 Bukharin, who had publicly endorsed the "class against class" tactic, privately wrote Humbert-Droz that he disagreed with it, and it is possible that Humbert-Droz shared his viewpoint. On many other matters, particularly internal Russian economic and political policies, Bukharin and Humbert-Droz were in complete agreement. See Robert V. Daniels, The Conscience of the Revolution, Communist Opposition in Soviet Russia (Cambridge, 1965), pp. 334-337; Richard C. Thornton, "The Emergence of a New Comintern Strategy for China: 1928", in: Milorad M. Drachkovitch and Branko Lazitch, The Comintern: Historical Highlights, Essays, Recollections, Documents (New York, 1966), pp. 87-88; Jules Humbert-Droz, L'Oeil de Moscou à Paris (Paris, 1964), pp. 256-257.

2 Classe contre classe, Latin Secretariat, Sixth Comintern congress, Jules Humbert-Droz, p. 233. Although Treint was ousted from the party's political bureau at the Lille congress, there were still many comrades who shared his enthusiasm for cooperation with the Socialists; after all, prior to the Comintern declaration that the period of "capitalist stabilization" had come to an end, Communist party organizations had been encouraged to cooperate with other parties of the left. Treint remained a member of the French party's central committee and of the Comintern executive committee until 1927; the following year he was expelled from the party.

${ }^{3}$ Classe contre classe, Latin St retariat, Sixth Comintern congress, Jules Humbert-Droz, p. 234. 
the political bureau on the error of its ways; he reminded party leaders of the Comintern's warnings against alliances with the "left bourgeoisie".' The criticism was not taken lightly; the French leaders rejected his critique and refused his suggestions for moral and political reform. D. Petrovsky, a Comintern representative temporarily stationed in Paris and soon to be named head of Agitprop (the Comintern agitation and propaganda division), sided with the French Communists against Humbert-Droz. And Petrovsky thought the grievance important enough to take to Moscow. ${ }^{2}$

1 Classe contre classe, Latin Secretariat, Sixth Comintern congress, Jules Humbert-Droz, p. 234; Jules Humbert-Droz, "The French Elections and the Policy of the Communist Party", in: The Communist International (official organ of the Comintern executive committee), V, No 12 (June 15, 1928), pp. 274-279.

On the eve of the party congress at Clichy (January 17-21, 1926), the Comintern executive committee had written to the French party: "It is true that the Party should try to form a powerful united front against Fascism, composed of all the workers, peasants and available groups in the middle class. But no political bloc should be formed with these petty bourgeois elements based on a programme of opposition to Fascism. It is essential in this big anti-Fascist movement to stress the predominant role of the proletariat and the role of the Communist Party as guide, the Party should become the centre of the class struggle against Fascism and not merely a section of the extreme left of an antiFascist opposition composed of bourgeois elements." Just before the Lille congress, the Comintern again suggested that: "Our Party, especially in the provinces, must be more active and itself take the initiative and give its demonstrations and propositions the character of a proletarian united front by endeavouring to attract the economic organisations to form a united front." See Humbert-Droz, "The French Elections and the Policy of the Communist Party," p. 276.

2 Jules Humbert-Droz, L'Oeil de Moscou à Paris, p. 241; Jules Humbert-Droz to Palmiro Togliatti, February 26, 1927 (Humbert-Droz papers). L'Oeil de Moscou à Paris reproduces the most important documents from the Humbert-Droz papers concerning the French Communist party. The Hoover Institution on War, Revolution, and Peace at Stanford, California possesses a microfilm copy of the Humbert-Droz papers.

Humbert-Droz had certainly not overstepped the bounds of his authority as a Comintern representative by criticizing the French party leadership. According to Comintern statutes, "The Executive Committee and its Presidium have the right to send their representatives into the various sections of the International. These representatives have the right to attend all the meetings and sessions of the central and local organizations of the sections to which they are sent. They can take actions against the Central Committee of the party to which they are sent." See Alfred Grosser, "Liens à travers les frontières", in: Les Internationales des partis politiques (Paris, n.d.), p. 8. Branko Lazitch has noted, however, that "... during the Bukharin period of Comintern leadership, the practice of assigning an emissary to the French Communist Party was abandoned... [since] Humbert-Droz had firmly in his hands the reins of direct control over the French Communist Party, with which he had numerous contacts." Branko Lazitch, "Two Instruments of Control by the Comintern: the Emissaries of the E.C.C.I. and the Party Representatives in Moscow", in: Drachkovitch and Lazitch, The Comintern: Historical Highlights, Essays, Recollections, Documents, p. 51. 
At the next meeting of the Latin Secretariat the French leaders lodged a formal complaint against Humbert-Droz. ${ }^{1}$ When a verbal confrontation between Petrovsky and Humbert-Droz failed to resolve the issue, Humbert-Droz persuaded Comintern president Nikolai Bukharin to appoint an arbitration committee in order to put a quick end to the dispute; Joseph Stalin, Otto Kuusinen, Egidio Gennari, John Thomas Murphy, Joseph Hacken, and Bukharin himself made up the six-man committee. ${ }^{2}$ Committee sessions began at the end of February 1927; members of the French party such as Maurice Thorez, a member of the party central committee and political bureau, who supported Humbert-Droz, and Albert Treint, who opposed him, testified and were questioned. Humbert-Droz feared that the Comintern would shy away from open condemnation of the French leadership, but his concern was unwarranted. In early April the committee drafted a letter which endorsed his criticism of the French party. ${ }^{3}$

Humbert-Droz wrote his colleague, Italian Communist leader Palmiro Togliatti, that although the terms of the Comintern letter to the French Communist party had been "softened", the meaning was "rather clear". The Comintern had ordered the French Communists to terminate their contacts with the "parties of the bourgeois left" which included the Socialists, and specifically to reject temporary agreements or joint election slates with the Socialists in order to minimize the "dangers of electoralism", Communist jargon for the error of mistaking election battles for the revolutionary struggle. The party was admonished to intensify its propaganda and recruitment in the factories, to exploit any crisis situation, and to strive for working-class unity. ${ }^{4}$

The April letter infuriated the French party's political bureau which demanded that exceptions be made to the Comintern instructions; Humbert-Droz complained to Comintern executive committee secretary Jean Crémet that "the exception had become the rule". 5 The French protest was brought before the Comintern executive committee, but two meetings devoted to the French question convinced its members that Humbert-Droz's appraisal of the situation had indeed been correct;

1 Humbert-Droz credited Albert Treint with masterminding the letter from the French party's political bureau which demanded his replacement as director of the Latin Secretariat. See Humbert-Droz to Togliatti, March 5, 1927 (HumbertDroz papers).

${ }^{2}$ Humbert-Droz to Togliatti, February 26, 1927 (Humbert-Droz papers).

3 Humbert-Droz to Togliatti, February 26, 1927, March 5, 1927, April 8, 1927 ; Jules Humbert-Droz to Jean Crémet, April 10, 1927 (Humbert-Droz papers). 4 Humbert Droz to Togliatti, April 8, 1927 (Humbert-Droz papers). Also see [Amicale des anciens membres du parti communiste français, ] Histoire du parti communiste français (Paris, [1960]) (three volumes), I, pp. 134-135.

5 Humbert-Droz to Crémet, April 10, 1927 (Humbert-Droz papers). 
the executive committee refused to modify its instructions, but did alter the wording. ${ }^{1}$ Despite the Comintern's verdict, the French leaders claimed victory, pretending that the final version of the resolution was what they had desired all along. This surprising interpretation, perhaps an attempt to save face, convinced Humbert-Droz that the French question was far from settled. He was "quite skeptical" whether the party would really change its political line. ${ }^{2}$

While French Communists debated their future political plans in the light of the Comintern instructions, the French government escalated its campaign of harassment against the Communist party. The Communists' anti-imperialist, anti-war policy made the party a perfect target for accusations of internal sabotage or betrayal of the national interest. In a speech at Constantine, Algeria on April 22, 1927, Minister of the Interior Albert Sarraut, a prominent Radical-Socialist politician, proclaimed: "Communism, there's the enemy!" "For the last few years", he continued, the French Communists "... have been trying to undermine the cornerstones of our great colonial edifice." 3 A month later in the Chamber of Deputies Sarraut added: "The 'Comintern of Moscow', the executive of the International, centralizes, gives the orders, and imposes the rules." "The Communists receive their commands from Moscow."4 French Communists would henceforth be depicted by government spokesmen as the willing agents of a foreign power.

So that Communist deputies could be jailed for their anti-war campaign, which, it was alleged, demoralized French troops, the government requested the Chamber of Deputies to deny them parliamentary immunity. Jacques Doriot, Paul Vaillant-Couturier, Jacques Duclos, André Marty, and Jean-Marie Clamamus were named in the government's request, but only in the case of Doriot, a youthful and dynamic orator, was the immunity lifted; Doriot was condemned to thirteen months in prison. ${ }^{5}$ Warrants were also issued for the arrest of Pierre Sémard, secretary-general of the party, Gaston Monmousseau, secretary-general of the Communist labor organization, the Confedéra-

1 Ibid.

2 Ibid.

3 Quoted in Jacques Fauvet, Histoire du parti communiste français (Paris, 1964-1965), I, p. 76.

4 Journal officiel de la République française, annales de la Chambre des Députés; Débats parlementaires, CXXXII (1927), May 27, 1927, p. 260.

5 Journal officiel de la République française, annales de la Chambre des Députés; Documents, CX (1927), Part 1, Annexe No 4279, p. 546; Annexe No 4323, p. 616; Annexe No 4375, p. 686; Annexe No 4380, p. 689. Also see Fauvet, Histoire du parti communiste français, I, p. 76. 
tion générale du travail unitaire, Marcel Cachin, François Chasseigne, secretary of the Committee Against the War in Morocco, Suzanne Girault, and Maurice Thorez; all were accused of encouraging soldiers to disobey their orders. ${ }^{1}$ The party was divided over whether to respect "bourgeois legality" and submit to imprisonment or to ignore the warrants and go into hiding. Marcel Cachin, a veteran party leader, voluntarily entered prison, while Maurice Thorez, determined to return the party to a revolutionary stance conforming with Comintern directives, preferred to dodge his would-be captors. It was clear, however, that the conflict between the bourgeois and the revolutionary mentality still existed within the party. ${ }^{2}$

The government continued its repressive campaign by proposing a new election law which, it was argued, would be a powerful deterrent to Communist election gains. "The only way ... to avoid having a united front with the Communist Party is to vote for the 'ballot by arrondissement'", wrote Socialist Fernand Bouisson, president of the Chamber of Deputies, in the Petit Provençal, the Radical-Socialist newspaper of Marseille. "I will go even further," he continued, "the 'ballot by arrondissement' is the only way that the number of Communist

1 Fauvet, Histoire du parti communiste français, I, p. 76; Histoire du parti communiste français: manuel (Paris, 1964), p. 200. This is an official history compiled by the Commission d'histoire auprès du comité central du parti communiste français.

${ }^{2}$ See Togliatti to Humbert-Droz, June 29, 1927 (Humbert-Droz papers).

3 The election law of 1919 had been a system of liste majoritaive which meant voting for a départemental slate of party candidates (some départements were divided into two or more election districts) elected by a simple plurality; in 1919 and 1924 it had brought two well-defined blocs to power: the conservative bloc national and the liberal or leftist cartel des gauches. Because the Radical-Socialist and Socialist parties disagreed on financial and monetary policies and because the Socialists refused to accept cabinet posts in the government, fissures were opened within the cartel. It soon became obvious that the joint election lists used in 1924 would be an impossibility for the elections of 1928 ; this automatically increased the chances of victory for the Communist and conservative parties. Since Radical Socialists and Socialists still desired to barter, a two-ballot system was devised to replace the party lists: candidates would be elected on the arrondissement rather than on the départemental level. To win election a candidate had to receive an absolute majority on the first ballot. If no candidate succeeded in obtaining the required number of votes, a second ballot was cast the following Sunday; a simple plurality sufficed to decide the winner of this contest. Thus, between the first and second ballots, Socialists could withdraw in favor of Radical-Socialists and vice versa in the hope that their combined voter strength would be large enough to defeat either the Communist or the conservative candidate. See François Goguel and Alfred Grosser, La Politique en France (Paris, 1964), pp. 81-82; Joel Colton, Léon Blum, humanist in politics (New York, 1966), p. 491; Peter Campbell, French Electoral Systems and Elections since 1789 (London, 1958), pp. 90-99. 
deputies in the Chamber can be reduced to eight or ten."1 Albert Sarraut commented: "If the 'ballot by arrondissement' is not voted, sixty or eighty Communists will enter the Chamber." 2 When the bill was passed on July 6,1927, only the Communists voted against it.

By Fall 1927 the Communist party was reeling under the blows of the government's measures; a new wave of arrests had resulted in the imprisonment of a majority of the members of the central committee and almost all the leaders of the political bureau, secretariat, and the Confédération générale du travail unitaire. ${ }^{3}$ At the same time, Jules Humbert-Droz, now co-director of the Comintern's Western European Bureau at Berlin, journeyed to Paris to inform the French Communists of the election tactic decided upon by the Comintern which was to be used in the elections of $1928 .^{4}$ The Comintern policy, referred to as "class against class", supposedly reflected altered world conditions; a period of capitalist stabilization had given way to one of capitalist disintegration which meant heightened class tensions. "Class against

1 Quoted in Gérard Walter, Histoire du parti communiste français (Paris, 1948), p. 185.

2 Ibid.

${ }^{3}$ Henri Barbé, Souvenirs de militant et de dirigeant communiste (manuscript, Hoover Institution on War, Revolution, and Peace at Stanford, California), p. 127. In 1926 Barbé was appointed secretary-general of the Communist Youth of France; in 1928 he was sent to Moscow as a delegate of the French party and of the youth organization. From 1928-1930, he served as secretary of the French Communist party's central committee and of the Comintern's executive committee. Barbé was ousted from the party in 1934.

Barbé, who was imprisoned in Santé prison from August 1927 to February 1928, reported that in Fall 1927 there were between seventy and eighty Communist leaders arrested. Nevertheless, the political life of the party continued. The prisoners were housed in a large, comfortable common cell and could receive visitors, newspapers, books, and documentation; they were even permitted to write newspaper articles under pseudonyms. Barbé noted that it was relatively easy to hold a meeting of all départemental and regional delegates during visitors' hours. The political bureau which operated from Santé prison was composed of Pierre Sémard, Benoît Frachon, Gaston Monmousseau, Jacques Doriot, Marcel Cachin, André Marty, Paul Vaillant-Couturier, François Chasseigne, Alfred Bernard, and Henri Barbé. See Barbé, Souvenirs, pp. 121-122, 125.

4 Humbert-Droz, L'Oeil de Moscou à Paris, p. 235. In a letter to historian Daniel R. Brower Humbert-Droz revealed that he had come up with the "class against class" slogan. Daniel R. Brower, The New Jacobins, the French Communist Party and the Popular Front (Ithaca, New York, 1968), p. 14.

5 In 1925 Comintern economist Eugen Varga defined capitalist stabilization as a period when "...no 'acute revolutionary situation' prevailed, e.g., that promising struggles for the conquest of power were not at hand" (Eugen Varga, "Ways and Obstacles to the World Revolution", in : The Communist International, No 18-19 (1925), pp. 77-96). The same year Comintern president Grigori Zinoviev emphasized that "...this stabilisation is partial, that it is relative, that it would be 
class" was a more precise statement of the instructions given to the French party in April. Henri Barbé recalled that the Comintern orders "... completely overturned the election campaign tactics of the party." "Prior to the directives," he noted, "in every election the Communist party withdrew its candidate whenever a left-wing candidate was in a better position to win the contest."1 The Comintern instructions forbade this practice. Barbé summarized the Comintern message:

"The French Communist party must break categorically with the
evil traditions which have made it like any other party. It must no

the greatest mistake to exaggerate it, and that it is temporary and may even be of short duration" (Grigori Zinoviev, "Eight Years of Revolution", in: The Communist International, No 18-19 (1925), pp. 6-7). In 1927 Stalin hinted that the period of capitalist stabilization might be giving way to one of capitalist disintegration, an analysis endorsed by the Sixth Comintern congress in 1928; Comintern spokesmen pointed to the growth of the USSR, the colonial national liberation movement, and the "leftward trend" of the working class as the outward signs of the crisis in world capitalism ("The Sixth Congress of the Comintern", in: The Communist International, V, No 5 (August 1, 1928), pp. 346348, and "The Comintern's Militant Task", in: The Communist International, V, No 2 (January 15,1928 ), pp. 26-31).

On the other hand, the theoretical basis for the "class against class" tactic might have only concealed political objectives; in 1924 Varga had to ask Zinoviev whether he should report on capitalist stabilization or capitalist disintegration (Milorad M. Drachkovitch and Branko Lazitch, "The Communist International", in: Milorad M. Drachkovitch, ed., The Revolutionary Internationals, 1864-1943 (Stanford, 1966), pp. 159-202). Since Stalin had defeated Trotsky in the internal Soviet power struggle, he might have decided to embarrass Bukharin, another potential rival, by adopting a political tactic with which Bukharin disagreed. Then too, the period of capitalist disintegration had important political implications for the Soviet Union. In May 1927 the Comintern had concluded that "the danger of war against the Soviet Union is becoming the most pressing question of the international labor movement" (Annie Kriegel, Les Internationales ouvrières (1864-1943) (Paris, 1964), p. 93). Again, in August 1927 the Comintern noted that "the danger of a counter-revolutionary war directed against the Soviet Union constitutes the gravest problem of the present situation." ("The Plenum of the Central Committee and Central Control Commission of the Communist Party of the Soviet Union", in: The Communist International, IV, No 14 (September 30, 1927), pp. 262-266). Moreover, rigid application of the "class against class" tactic would be one more step in the bolshevization of the French Communist party; it would further alienate comrades with socialdemocratic sympathies and at the same time strengthen Comintern loyalists. Since 1924 bolshevization had been "the most important task of the Communist International" but the French party had managed to avoid the effects of this policy, perhaps because Stalin and Comintern officials were more concerned with German than with French matters (Drachkovitch and Lazitch, "The Communist International", p. 180). But once the German Communist party had been bolshevized, it was the French party's turn.

1 Barbé, Souvenirs, p. 127. 
longer consider itself a party of the left and of the French republican family. It must no longer associate itself in the false struggle of the reds against the whites. It must put into practice a tactic of intransigeant combat on the electoral level. No more withdrawals for the left-wing candidates, even the Socialists. No more joint election slates with the Socialist party candidate. Even when there is a risk of permitting a reactionary to be elected, the Communist party must keep its candidate in the race." 1

Barbe remembered that the Comintern's instructions "...hit us on the head without our being prepared for it"; he noted that some party members were surprised, others were indignant. ${ }^{2}$

As Barbé had reported, the announcement of the Comintern resolution received a mixed reaction from the French party leadership. Marcel Cachin was against the new policy as was Renaud Jean, the party's rural tactician from Lot-et-Garonne. ${ }^{3}$ Jacques Doriot equivocated; he said he approved of the tactic, but when asked by Barbé how many exceptions he envisioned, Doriot replied: "in 580 out of 610 election districts". "Maurice Thorez, Pierre Sémard, Gaston Monmousseau, Benoît Frachon, and Barbé pronounced in favor of the Comintern policy. ${ }^{5}$

Despite the lack of agreement with the Comintern instructions, the French Communist party's central committee drafted an open letter to party members explaining the new election tactic. ${ }^{6}$ The letter endorsed the Comintern resolution, scolding the party for electoralism and opportunism, blaming the members for insufficient appreciation of the political and economic situation, reproaching the local cells for a lack of worker and peasant organization, and denouncing any contact with the middle class. At the same time, however, the letter proposed an election agreement with the Socialists. ${ }^{7}$

1 Barbé, Souvenirs, pp. 127-128. André Ferrat pointed out that "'red' in election vocabulary meant 'communists, socialists, radicals, etc...' while 'white' meant the 'reaction', that is the parties of the Republican Federation, the royalists, etc..." Histoire du parti communiste français (Paris, 1931) (edited by the central committee of the French Communist party), p. 233.

${ }^{2}$ Barbé, Souvenirs, p. 128.

3 Ibid.

Ibid., pp. 128, 133.

${ }^{5}$ Ibid., pp. 128, 134. Barbé later estimated that if the party membership had been permitted to vote, the Comintern demands would have been rejected; moreover, he noted that "...no one understood the true nature, the authentic reasons, and the underlying realities..." of the Comintern decision. See Barbé, Souvenirs, pp. 129, 133 .

- L'Humanité, November 19, 1927.

7 Ibid. 
"The Communist Party candidate will oppose the bourgeois candidate on the second as on the first ballot. In run-off elections Communists will not have to vote for a Daladier against a Poincaré or for a Painlevé against a Maginot.

The Communist Party will immediately propose to the Socialist Party the formation of a Workers' Bloc [Bloc ouvrier] for the second ballot with the aim of maintaining a Socialist or a Communist against all the bourgeois candidates. The reciprocal withdrawal by the two parties will be conditional to the acceptance of a minimum program.

The Communist Party declares that in case the Socialist Party rejects its proposal for a Worker and Peasant Bloc [Bloc ouvrier et paysan], it reserves the right to maintain a proletarian candidate against all the Socialist leaders who are performing a counterrevolutionary task and who declare themselves defenders of bourgeois democracy against Communism."1

To some, the proposal of a minimum program with the Socialists appeared in direct violation of Comintern orders; this at least was the assessment made by Cahiers $d u$ communisme, the pro-Comintern theoretical journal of the French Communist party. ${ }^{2}$ Barbé, however, insisted that the minimum program, especially the insulting third paragraph, was designed to enrage the Socialists, forcing them to reject the Communist proposals, and providing the Communists with a convenient albeit transparent casus belli. ${ }^{3}$ On the other hand, many Communists undoubtedly hoped the offer would be accepted by the Socialists; it seemed to them the only way of surviving the disastrous Comintern policy.4

Jacques Doriot was one of the leaders who doubted the wisdom of Comintern policy. Doriot was convinced that the election tactic would alienate the masses of Socialist and left-wing voters who were sympathetic to the Communist party; he added that he believed that the "great majority of the party shared this fear". Doriot argued that the

1 Ibid.

${ }^{2}$ Cahiers du communisme, December 1, 1927.

${ }^{3}$ Barbé, Souvenirs, p. 133. Annie Kriegel has pointed out that the Socialists' refusal of the Communist offer was a foregone conclusion since the minimum program stipulated that French foreign policy should be directed in the interests of the "Soviet homeland". Les Internationales ouvrières, p. 97. A partial text of the Communist party minimum program is printed in Walter, Histoire du parti communiste français, pp. 187-188; a more complete version of the party program is printed in G. Rougeron, Le Département de l'Allier sous la troisième république (1870-1940) (Paris, 1965), p. 204.

4 See Ferrat, Histoire du parti communiste français, p. 225. 
Communists' refusal to cooperate with the Socialists to prevent the election of reactionaries, capitalists, and members of the bourgeoisie would not be understood by the working class. To avoid a misunderstanding of Communist intentions, Doriot proposed that "in every case where the collusion, or the union of the Socialists with the bourgeoisie does not appear sufficiently clear to the masses, even if the Socialists say that they will not accept our proposals for a front unique, we [should] withdraw... our candidate, in order not to bear the responsibility for electing a reactionary [or] a bourgeois candidate."1

Renaud Jean openly opposed the election tactic; he disliked the highhanded way which the letter drafted by the party's central committee had been submitted to the party membership and he too feared the repercussions of the new tactic on the masses. To Renaud Jean the central committee's letter exemplified the lack of communication between the leaders and the led; he insisted that the average party member was never consulted, never allowed to discuss an issue or to express an opinion, and never permitted to play a role in the leadership of the party. ${ }^{2}$ Moreover, Renaud Jean disagreed with the Comintern analysis of the French socio-economic situation. At the January meeting of the central committee he questioned whether the economic situation had really changed since 1924, as the Comintern claimed, intensifying the antagonisms between the middle class and the proletariat and radicalizing the masses; he could see no evidence to justify the Comintern's combative "class against class" policy. Consequently, he proposed a second ballot withdrawal in favor of the leading Socialist or Radical-Socialist candidate. ${ }^{3}$

The January meeting of the central committee was a continuation of the debate which had raged within the party since November. After heated discussion, the political bureau proposed a compromise resolution which significantly modified the central committee's letter. ${ }^{4}$ The essential passage of this resolution read:

"The National Conference of the Party will definitely confirm our

\footnotetext{
1 Classe contre classe, Ninth Plenum ECCI, Jacques Doriot, pp. 76-77. The Ninth Plenum of the executive committee of the Communist International met in Moscow from February 9-25, 1928. Classe contre classe reproduces the speeches and the report of the French commission of the Ninth Plenum and the resolution of the Comintern executive committee.

${ }^{2}$ Classe contre classe, Latin Secretariat, Sixth Comintern congress, Renaud Jean, pp. 130, 133,

${ }^{3}$ Classe contre classe, préface, Pierre Sémard, p. 7 ; Classe contre classe, Ninth Plenum ECCI, Jacques Doriot, p. 71 ; Classe contre classe, Ninth Plenum ECCI, Richard Schuller, pp. 41-42.

4 Classe contre classe, préface, Pierre Sémard, p. 6.
} 
election tactic of the systematic maintenance of all Communist candidates against all the bourgeois and Socialist candidates having rejected our proposals for a Worker and Peasant Bloc, except in those cases determined by the Central Committee in agreement with the Comintern."1

The resolution passed by a vote of 21 to 13. Doriot and Alfred Bernard, both members of the political bureau, had voted for the resolution in the hope it would delay action by the central committee until a meeting with Comintern officials could be scheduled where they might express their reservations to Comintern policy. But party chieftain Pierre Sémard was convinced that both Doriot and Bernard counted on the compromise resolution to nullify the "class against class" tactic. ${ }^{2}$

Once more Humbert-Droz was dispatched to Paris, this time to ensure the adoption of the Comintern policy by the French party's national conference held at the end of January. He spoke of the need for international Communist unity and of the necessity to re-affirm the revolutionary character of the French Communist party. ${ }^{3}$

"You cannot accept only a part, even the largest part, of the 'open letter' and the tactics that it prescribes; it is necessary to accept it entirely after a profound discussion and an exact comprehension.

... The Communist tactic is based on the correct analysis that we give to the situation."4

And what if the masses should not understand the new Communist tactic? Would this not alienate them from the party?

"It has already happened in the history of the Bolshevik Party that the masses have not immediately understood us, but as soon as they understood the true road they did not want to forgive the Communists for not having shown it to them sooner. One must look farther ahead than the present.

To continue the old tactic of systematic withdrawal and to lead the struggle against bourgeois democracy are two irreconcilable things. Democratic illusions are presently the greatest danger for the

1 Ibid. (author's emphasis).

2 Classe contre classe, préface, Pierre Sémard, pp. 6-8. Both the Amicale des anciens membres du parti communiste français and André Ferrat recorded the central committee vote as 23-13. Histoire du parti communiste français, I, p. 139; Ferrat, Histoire du parti communiste français, p. 227.

${ }^{3}$ L'Humanité, February 2, 1928.

4 Ibid. 
working class and to encourage them indirectly would drag our party down with their collapse...."1

Even with all his efforts, the resolution adopted by the national conference still contained the loophole drafted into the political bureau's compromise resolution of January: "If the Central Committee believes it is necessary in some cases to make exceptions, it will make concrete proposals to the Comintern which will examine them together with the Central Committee."2

After the national conference the debate over the election tactic continued more furiously. The entire "French question" was studied by the Ninth Plenum of the Comintern executive committee (February 9-25, 1928). Here the leaders of the European Communist parties, including French chiefs Pierre Sémard, Jacques Doriot, and Maurice Thorez, examined the French situation. Doriot still voiced his reservations about the "class against class" tactic, but finally agreed to accept the Comintern decision; Sémard and Thorez reaffirmed their support of Comintern policy. ${ }^{3}$ Nikolai Bukharin remarked that "...there had always been a latent crisis in the relations between the central committee of the French Communist party and the executive committee of the Comintern", but at present the situation was "much less serious"; he noted that the pressure from above by the Comintern and the pressure from below by the party members had created a situation in which the central committee of the French party had finally realized the necessity of modifying its position. ${ }^{4}$ Despite Bukharin's jab at the party leadership, the Comintern resolution on the French question (February 25, 1928), endorsed the "election tactic decided on by the national conference" and noted that the French party had made "important progress towards the formation of a real bolshevik party"; the French party was praised for its "political maturity", and its "intense political life", and its ability "to redress its political position".5 Nonetheless, neither the discussions nor the

1 Ibid.

${ }^{2}$ Classe contre classe, Ninth Plenum ECCI, Pierre Sémard, p. 26.

${ }^{3}$ Classe contre classe, Ninth Plenum ECCI, Jacques Doriot, p. 77. Doriot was the only opponent of the "class against class" tactic who might have led a successful rebellion against it. Although he finally submitted to Comintern orders, the chastisement he received embittered him against the Comintern leadership and many of his colleagues in the French party. See Gilbert D. Allardyce, "The Political Transition of Jacques Doriot", in: Journal of Contemporary History, I, No 1 (1966), pp. 57-58.

${ }^{4}$ Classe contre classe, Ninth Plenum ECCI, Nikolai Bukharin, p. 85.

5 Classe contre classe, Ninth Plenum ECCI, Résolution du IXe Exécutif sur la question française, pp. 103-104. The French ambassador to Moscow, Jean 
resolutions dispelled the doubts that plagued so many of the French Communist leaders.

Boris Souvarine, who had been ousted from the French party by the Comintern in 1924, considered the theoretical basis of the "class against class" tactic to be ridiculous. Writing in the Bulletin communiste which he had founded, Souvarine recalled that "the idea of two opposing classes is from an old idea of Ferdinand Lassalle"; he noted that Marx and Engels had spoken of the "hierarchical organization of society" and the "graduated scale of social conditions". Furthermore, he condemned the appeal to the Socialist masses to oppose their leaders; Souvarine was certain that the bond between leaders and led was a real one.

"The working class will not follow the advice of irresponsible pseudo-revolutionary politicians. The majority of Communists, themselves, will scorn the orders of an unprincipled clique and will instinctively understand that when the doctrine and tradition of Communism are distorted by those who pretend to be its heirs, disobedience is the most sacred of rights and the most imperious of duties."1

Souvarine's interpretation was denounced by L'Internationale communiste, the bimonthly publication of the Comintern executive committee; the duty of the Communist party was to break the connection between the grande bourgeoisie and the petite bourgeoisie and to rally the latter and the peasants around the only proletarian party. ${ }^{2}$

Herbette, sent a translation of the entire Comintern resolution to Minister of Foreign Affairs Aristide Briand. He thought it particularly important to point out one sentence: "The [Comintern] executive committee, while fully approving the decisions of the national conference, demands a firm and systematic application of the new line of conduct from the central committee [of the French Communist party]." To Herbette the Comintern "demands" of the French Communist party underscored the "incompatibility between the engagements assumed by the Soviet government at the time of the recognition of the USSR by France and the hospitality that it officially gives to such demonstrations as the recent plenary session of the central committee of the Communist International, a session during which a resolution was voted which constitutes an intolerable interference in the political life of France." Ambassador Jean Herbette to Foreign Minister Aristide Briand, March 20, 1928, in: [Jean Herbette,] Un diplomate français parle du péril bolchéviste, rapports de Jean Herbette, ambassadeur de France à Moscou de 1927 à 1931 (Les Origines de la guerre de 1939, Documents secrets des archives européennes publiés par la commission des archives du ministère des affaires étrangères du Reich) (Berlin, [1943]), pp. 89-98.

1 Boris Souvarine, "La tactique communiste et les élections", in: Bulletin communiste, January-March, 1928.

2 L'Internationale communiste, June 1, 1928. 
The majority of French Communists who opposed the Comintern instructions did not quibble over theoretical statements; they opposed the Comintern's intrusion in matters in which they felt they were the experts. Perhaps some feared the subordination of the interests of French Communism to those of world communism, or the increasing authority of the Comintern, or the bolshevization of the French party. Many French Communists begrudged their fealty to the Comintern; in part this was due to the personalities and social-democratic background of many of the French leaders; and in part it was due to the Comintern's tendency to acquiesce in the necessities of Soviet foreign policy. ${ }^{1}$

The French Communist party entered the final period of preelection preparations uncertain and divided. Disgust at submission to the Comintern heightened by the suspicion that the decisions were not in the best interests of their own party angered some French leaders. Others obediently accepted the Comintern instructions. Yet a third group gave lip service to the Comintern policy, but secretly questioned its value.

The "open letter" to party members had contained the proposal of a minimum program and reciprocal withdrawals at the second ballot with Socialist party; the Socialists left the letter unanswered. ${ }^{2}$ Paul Faure, secretary-general of the Socialist party, lashed out at the Communists: "Even if all our leaders should be faced with defeat, we will not sign these insolent conditions", and Léon Blum, party leader and political director of the Socialist daily newspaper, Le Populaire, retorted: "It goes without saying that we refuse the insolent offer contained in the Communist proposal." "We will not even give it the honor of a reply."3 The Socialist press accused the Communists of

1 Barbé later alleged a sinister reason for the new election tactic: an attempt to use the French Communist party for the Soviet Union's own economic interests Although many French businessmen loathed communism they seemed to want trade agreements with the USSR. A setback for French Communism at the polls might mean a step forward in Franco-Soviet economic cooperation; perhaps the victory of the Union nationale would give French businessmen the security they desired at home to pursue an adventurous commercial policy abroad; a victory for the French Communists might produce the opposite effect (Barbé, Souvenirs, pp. 134-136). As farfetched as the explanation sounded, it was true that during the period of the Popular Front, the Kremlin worried about the effect of French Communist victories on Franco-Soviet relations. Georges Lefranc, Le Front populaire (Paris, 1965), pp. 58-59.

2 See Walter, Histoire du parti communiste français, pp. 187-188. The Socialists printed the Communist party program in Le Populaire, November 25, 1927. ${ }^{3}$ Quoted in Fauvet, Histoire du parti communiste français, I, pp. 79-80. 
placing "the republic in peril", of playing into the hands of the reactionaries, and of opening "the road to fascism". 1

The rejection of the Communist proposals was motivated by indignation as much as by calculation. Any deal with the Communists would limit the Socialists' bargaining power. Since the "class against class" tactic might collapse after the first ballot, there was little reason to alienate potential support from the Radical-Socialists by insinuating they were reactionaries. Blum preferred a middle course: to defeat the reactionary candidate the Socialists would withdraw in favor of the candidate with the best chance of winning, whether he was Communist, Republican-Socialist, Radical-Socialist, or even, Moderate Republican. ${ }^{2}$

The Seine federation of the Socialist party, the stronghold of the party's pro-Communist wing, opened its congress in Paris on December 4 th with a debate on the election tactic. Jean-Baptiste Séverac championed the Blum formula while Jean Longuet wanted the local federations to have complete freedom to choose the candidate for whom they would withdraw. Jean Zyromski preferred a strong statement categorically forbidding anti-Communist alliances and Léon Maigret went even further, asking for alliance with the Communists and withdrawals exclusively in their favor. ${ }^{3}$ On December 19 th the congress voted to adopt the Blum-Séverac formula; a similar resolution would be adopted by the Socialist party congress on December 26-27, 1927.4

"The Congress expresses its confidence in the federations to assure withdrawal on the second ballot for the candidate - whatever his political group - who has the best chances of defeating the [reactionary candidate]...."5

Once the Socialists had decided upon their election tactic, the Communists launched a series of editorial attacks, beginning with a diatribe by the political bureau on January 1st. The Communists accused the Socialists of compromise and collaboration with the middle class, of supporting a capitalist fiscal policy, of defending French imperialism, of encouraging the rationalization of the capitalist order, and of abandoning immediate reforms. The editorial ended with the slogan: "Against the Union nationale and its supporters the Socialist leaders!"6

1 Walter, Histoire du parti communiste français, p. 188.

2 Le Populaire, December 2, 3, 4, 1927.

${ }^{3}$ Le Populaire, December 5, 1927.

4 Le Populaire, December 19, 1927.

5 Le Populaire, December 30, 1927.

' L'Humanité, January 1, 1928. Communist poet Louis Aragon likened the "class against class" tactic to military struggle: "Fire on Léon Blum / Fire on Boncour Frossard Déat / Fire on the trained bears of the social-democracy." Louis Aragon, The Red Front (translated by e. e. cummings) (Chapel Hill, 
A violent controversy erupted over who was playing into the hands of the reactionaries. The Socialists were accused of opportunism by refusing to define the reactionary political elements. "It is a tactic of confusion of classes...", wrote Pierre Sémard, "which aims at an alliance of all the bourgeois and petty bourgeois parties that call themselves partisans of democracy and... [at] ministerial participation". ${ }^{1}$ Socialists, on the other hand, saw the Communists as the dupes of a policy destined to split leftist ranks and assist the Union Nationale.

When the Communists continued their campaign to persuade Socialist workers and candidates to form a united front on the basis of a reform program, the reaction of the Socialist leadership was direct and to the point: "No Socialist candidate is nor will be authorized to accept proposals of a united front or of a common program...."2 Paul Faure was convinced that the Communist election policy was one "... of suicide and treason, in violation of the history and tradition of the French labor movement...."3

Right-wing Socialist leaders such as Joseph Paul-Boncour, Pierre Renaudel, and Vicent Auriol, hoped for an alliance with the RadicalSocialists, while the left-wing of the Socialist party, led by Jean Zyromski, still pressed for cooperation with the Communists. Blum refused commitment to either faction; he counted on the collapse of the Communists' "class against class" tactic after the first ballot and he hoped for cooperation with the Radical-Socialist party. ${ }^{4}$

North Carolina, 1933). In Allier département Communist posters read: "Against the Union Nationale and its Socialist accomplices, Against the parliamentary regime on its knees before the moneyed powers, Against the lying bourgeois democracy of which you are the victims, Up with the flag of the Workers' and Peasants' Government, prepare yourselves for the revolutionary capture of power which alone will free you from the yoke of your exploiters." Rougeron, Le Département de l'Allier sous la troisième république, p. 204.

1 Pierre Sémard, "Le triomphe du révisionisme", in: L'Humanité, January 2, 1928.

2 Pierre Sémard, "Qui fait le jeu de la réaction?”, in: L'Humanité, February 8, 1928; Paul Faure, "Les communistes: fourriers de la réaction"!, in: Le Populaire, February 10, 1928.

'Paul Faure, "Les communistes: fourriers de la réaction!", in: Le Populaire, February 10, 1928.

'L'Humanité, December 26, 1927. The outcome of the Radical-Socialist party congress had jeopardized the hopes for cooperation between Radicals and Socialists; one group of Radicals, led by Edouard Herriot and Paul Painlevé, marched into the ranks of the conservative, nationalist Union nationale, while the rest of the party under the nominal presidency of Edouard Daladier preferred the Socialists, yet feared the consequences of a total break with Raymond Poincaré, the titular head of the Union nationale. Michel Soulié, La vie politique d' Edouard Herriot (Paris, 1962), pp. 292-293. 
The balloting on April 22nd was disastrous for the Communist party. Of the 187 deputies elected on the first ballot, not one was a Communist. ${ }^{1}$ Henri Barbé, who was in Moscow at the time, was not in the least alarmed. In a report to Humbert-Droz on the results of the first ballot, he praised the "class against class" tactic and recommended a final appeal to the Socialists to accept the minimum program of the Bloc ouvrier et paysan. If the Socialists refused once again, the Communists would continue to oppose them on the second ballot. ${ }^{2}$

The Kremlin took a different view of the situation. Barbé, HumbertDroz, and Bukharin were called to a special meeting with Stalin on April 27th. Stalin demanded to know the number of Socialists that could be elected by Communist support and the number of Communists that could be elected by Socialist votes. Barbé supplied the answer: in about twenty-five election districts Communists could be elected by Socialists and in about fifty election districts Communists could elect Socialists. Stalin immediately decided that a reversal in tactics was necessary. A telegram had to be sent to party headquarters in Paris to order the formation of an alliance with the Socialists on a give-andtake basis: "I will withdraw my candidates for you if you will withdraw yours for me." Barbé protested that in view of the bitter internal party struggle and the long drawn-out campaign, an abrupt about-face would only confuse and dishearten the party faithful. ${ }^{3}$ Humbert-Droz supported Barbé; he estimated that by continuing the "class against class" tactic the Communists were assured of at least ten seats in the Chamber of Deputies. At this point Stalin conceded to HumbertDroz's argumentation: "You know French conditions better than I, so forget the telegram."4

Barbé later recalled a second incident in Moscow. Taken to the Soviet Commissariat of Foreign Affairs, he was greeted by Foreign Minister Georgii V. Chicherin, who, after expressing approval of the election tactic, urged that several exceptions be made, specifically in the case of Henri Torrès, a lawyer, influential in commercial and diplomatic circles. Barbé was doubly wounded: first at the thought that the Soviet Foreign Office would ask for the election of a reactionary and second, because the candidate in question had been ousted from the French Communist party five years before and was considered a

1 Georges Lachapelle, Élections législatives: 22-29 avril, 1928 (Paris, 1928), p. x.

2 Barbé, Souvenirs, p. 160.

3 Barbe, Souvenirs, pp. 160-163. Humbert-Droz quoted Stalin as saying that the Soviet Union could not accept the fact there would be no Communist deputies in the French Chamber of Deputies. Humbert-Droz, L'Oeil de Moscou à Paris, p. 241.

4 Humbert-Droz, L'Oeil de Moscou à Paris, pp. 241-242. 
crude adventurer. Barbé refused to recommend such action to the party leadership in Paris. The interview ended on a very unfriendly note. ${ }^{1}$

In Paris the Communist party appeared to be following Comintern orders to the letter. Pierre Sémard reiterated the "class against class" policy in an editorial two days after the first ballot, which sent a shiver of fear into leftist ranks; surely the Communist tactic, by dividing the left, would facilitate a right-wing victory. ${ }^{2}$ The RadicalSocialist newspaper, Volonté, pleaded with the Communists to join the struggle against the reactionaries. ${ }^{3}$ On the other hand, the Socialist Fédération du Rhône telegraphed party headquarters in Paris to request that Socialist candidates be maintained in all election districts and withdrawn only if the Communists reciprocated throughout France. ${ }^{4}$ But the following day the Conseil féderal de la Seine decided on the withdrawal of Socialist candidates wherever the Communist candidate was in a more favorable position; the Socialist withdrawal, however, would not be accompanied by a formal endorsement of the Communist candidate. ${ }^{5}$ Blum was a bit embarrassed; he had counted on the abandonment of the "class against class" tactic. He belatedly called on Communist workers to form a united front against capitalism and the "reaction". 6

It was now up to the Socialist leaders to convince Communist voters to disobey the orders of their party chiefs and to cast their votes for Socialist candidates. Socialists concentrated on the familiar themes of working class unity and the danger from the right. And in an attempt to discredit the Communist leadership, to portray them as puppets of the Soviet government, the Socialists gave wide publicity to a story circulated by André Le Troquer, a Socialist deputy up for reelection. Le Troquer alleged that Renaud Jean and Jacques Doriot had been sent to Berlin by the political bureau of the French Communist party to plead with Soviet Ambassador Maxim Litvinov for the abandonment of the "class against class" tactic; Le Troquer implied that the political bureau had finally realized that Moscow's orders did not conform with the interests or the desires of French Communists. Allegedly rebuked and denied any concession from the Soviet diplomat, Renaud Jean

1 Barbé, Souvenirs, pp. 163-166.

${ }^{2}$ L'Humanité, April 24, 1928.

${ }^{3}$ Le Temps, April 25, 1928.

4 Ibid.

Le Temps, April 26, 1928. Socialist candidates withdrew in favor of Communists in Allier, Aube, Creuse, Loire, Nord, and Seine-et-Oise. See Le Populaire, April 26, 1928 and Le Temps, April 26, 28, 1928.

- Le Populaire, April 25, 1928. 
returned to report his failure to Marcel Cachin. Cachin was quoted as saying to Pierre Sémard: "If I am defeated [in the election], I will leave the Communist Party and my friends and I will found a new party."1

The publication of Le Troquer's story brought sharp denials from L'Humanité and from Soviet news agency Tass:

"The decision which will be applied Sunday [April 29] has not been taken under pressure of the Russian government. The Russian government has not intervened at any moment - neither in the discussion, nor in the decision."2

Whether this French version of the Zinoviev letter affair had any basis in fact made little difference. It did give the Socialists a weapon to wield against the Communist leaders.

The Socialists and Radicals went down to defeat on April 29th; the Socialists lost three seats in the Chamber of Deputies and the RadicalSocialists fifteen. Sixty-seven deputies of the right and right-center had been elected due to the discipline of the Communist voters as well as the defection of the Radical voters; more than 400,000 voters who had cast their first-ballot votes for the Radical candidates preferred to cast their second ballot votes for Moderates rather than for Socialists. ${ }^{3}$ Yet it was Socialist and Communist votes that helped many Radical candidates; evidently some Communist voters preferred to disobey party orders and vote for Socialists or Radical-Socialists rather than "wasting" their votes on Communist candidates who were certain to lose. ${ }^{4}$

1 Ibid. Blum quoted Le Troquer as reporting that Litvinov had told Renaud Jean: "Don't discuss, obey!" (Léon Blum, "Les vraies raisons de la tactique des communistes", in: Le Populaire, April 26, 1928). The following day Le Populaire reported that Le Troquer stood by his story, but now claimed that Renaud Jean had talked with Manuilskii not Litvinov.

${ }^{2}$ L'Humanité, April 27, 1928. Also see Le Temps, April 28, 1928.

3 François Goguel, La Politique des partis sous la troisième république (Paris, 1946), pp. 246-247; Campbell, French Electoral Systems, p. 98. The Communists were responsible for losing at least 36 seats for the Socialists and RadicalSocialists. Édouard Bonnefous, Histoire politique de la troisième république (Paris, 1960), IV, 251.

4 Soulié, La vie politique d'Édouard Herriot, pp. 294-295. Communist votes aided the election of 58 Socialists, 10 Republican-Socialists and 37 Radical-Socialists. Bonnefous, Histoire politique de la troisième république, IV, pp. 251-252. François Goguel noted the degree to which the ballot by arrondissement had worked against "extremist parliamentary representation": the Communists received $1,064,000$ votes on the first ballot $(11.38$ per cent of the votes cast in metropolitan France), yet only 14 Communist deputies were elected (2.3 per cent of the seats in the Chamber of Deputies) (La politique des partis sous la troisième 
Jules Humbert-Droz had predicted that the Communist party would have about ten seats in the new Chamber of Deputies; in fact, they had fourteen. But the election had been costly. Reduced to one-half their former parliamentary strength, confronted with a 30-40 percent voter defection to the Socialist and Radical camps and stunned by the defeats of Renaud Jean, André Marty, Paul Vaillant-Couturier, Henri Barbé, and Maurice Thorez, the Communists began to analyze the results. ${ }^{1}$

Had the masses understood the new tactic and followed the party's dictates? In nine départements, the traditional strongholds of party loyalty (Ardennes, Gard, Nord, Haut-Rhin, Rhône, Seine, Seine-etOise, Seine-Inferieure, Haute-Vienne), the vote loss on the second ballot was less than 10 per cent of the vote on the first ballot. ${ }^{2}$ The Communists lost about 50 per cent of their first ballot vote in Eure-etLoir, Gironde, Maine-et-Loire, Meurthe-et-Moselle, Oise, and Seine-etMarne; between 60 and 70 per cent in Gers, Ille-et-Vilaine, Isère, Jura, Landes, and Morbihan; and between 80 and 90 per cent in Aube, Creuse, Doubs, Indre, Nièvre, Saône-et-Loire, Sarthe, and Yonne. ${ }^{3}$ In Nièvre, the Communist voters preferred to remain faithful to the "republican discipline" and deserted the party in large numbers; in only two election districts was there a respectable second ballot vote, but in those districts the Communist candidate was le plus républicain. ${ }^{4}$ The Communist voter, not unlike some of the party leaders, was reluctant to accept swift and brutal changes in doctrine and policy. It was only in the most militant bastions of Communism that "republican discipline" was sacrificed to "class against class".

Had the party leadership remained loyal to the Comintern policy? The majority of local Communist officials supported the "class against class" tactic. In the 422 second ballot elections, Communists ran in 364 ; since Communist candidates had led on the first ballot in about 35 election districts where the retention of the candidates would be a foregone conclusion, the incidence of party disobedience can be estima-

république, p. 246). In 1924 the Communists polled 876,000 votes (9.8 per cent of the votes cast) and won 26 seats in the Chamber of Deputies (4.6 per cent of the seats). Campbell, French Electoral Systems, p. 97.

${ }^{1}$ L'Humanité, April 30, June 2, 19, 1928; Le Temps, May 1, 1928. The Communist leadership probably found small consolation in the defeat of Léon Blum by Communist Jacques Duclos; on the other hand Paul Faure was elected with Communist support. Fauvet, Histoire du parti communiste français, I, p. 81 . 2 Ferrat, Histoire du parti communiste français, p. 234; Walter, Histoire du parti communiste français, p. 192.

${ }^{3}$ Lachapelle, Elections législatives, p. x; Walter, Histoire du parti communiste français, p. 192.

4 Jean Pataut, Sociologie électorale de la Nièvre au XXe siècle, 1902-1951 (Paris, n.d.). I, pp. 56, 158. 
ted at 16 or 17 per cent and may have been higher. ${ }^{1}$ The départemental committees of Basses-Alpes, Aube, Indre, and Somme were chastised for breaking party discipline to form Blocs des rouges and in CharenteInférieure, Nièvre, Saône-et-Loire, and Yonne, although Communists were maintained at the second ballot, all work of propaganda and agitation was neglected. Much of the provincial press lapsed into passivity, refusing to attack the Socialists and in many cases openly calling for the formation of leftist blocs. ${ }^{2}$

Not all blame for indiscipline can be placed on the lower echelons of the Communist party. As early as April 26th, the party secretariat hedged on the election strategy to be followed:

"The party headquarters has communicated its decisions to the regional groups as to the attitude to take on the second ballot. It has indicated the election districts in which - our campaign having been only a campaign of principle and the number of votes being small - our candidate can retire without endorsing another candidate."3

At the same time the secretariat mentioned two districts (Forcalquier in Basses-Alpes and the first district of Avesnes in the Nord) where Communist candidates would be withdrawn and Socialist candidates endorsed by the Communist party; in the first case it was because the opposition candidate was "a personality particularly representative of finance and industry" and in the second because the Socialist party had agreed to accept the Communist proposals for a united front. ${ }^{4}$ Undoubtedly the most blatant case of electioneering was in AlsaceLorraine where an alliance was formed with Catholic autonomists and regionalists which resulted in the election of three Communist deputies from Alsace and another as mayor of Strasbourg. ${ }^{5}$

At the National Conference of the French Communist party (June 18-21, 1928) Pierre Sémard attributed the party's poor performance in the elections to an inadequate understanding of the "class against class" tactic and opportunism in the party ranks. ${ }^{6}$ At the Comintern Congress in Moscow Sémard and Maurice Thorez repeated the party's excuses: an unwillingness to break with "republican discipline", a lack of understanding by the masses, sabotage on the part of certain

1 Lachapelle, Elections législatives, p. $\mathbf{x}$.

${ }^{2}$ L'Humanité, June 2, 1928.

${ }^{3}$ L'Humanité, April 26, 1928.

4 Ibid.

${ }^{5}$ Le Temps, May 1, 1928; F. Borkenau, World Communism: a history of the Communist International (Ann Arbor, 1962), p. 335.

6 L'Humanité, June 19, 20, 22, 1928. 
party chiefs who failed to pass on party directives and passivity on the part of others. ${ }^{1}$ Jules Humbert-Droz, on the other hand, thought the "class against class" tactic had been a success; as a Comintern spokesman he naturally desired to prove the correctness of the Comintern policy.

"Did the masses understand the attitude of the Party? Some French comrades doubt this, but the election results provide a clear-cut reply to this question. The mass of the workers and a large number of peasants welcomed the Party tactics and expressed their confidence in it. The Communist Party put up a good fight against the National Union, the old Cartel, and especially against the Socialist Party and its imperialist policy. The workers understood this campaign."2

Humbert-Droz noted that the party had become stronger; "in spite of government oppression and the fierce campaign against it, the Party increased its vote by more than 20 per cent...."3

Although it was true that the Communist party had won almost 200,000 more votes in 1928 than in 1924, that these increases had come in industrial regions where Socialist influence was strong, and that the Communist party could boast of being the strongest party in the working class districts of Paris and the suburbs, the 1928 election campaign had revealed important weaknesses, such as the dissension among the leaders of the French party. ${ }^{4}$ To those who supported the Comintern, the future of the French Communist party was inextricably connected with that of the Communist International and success or failure could only be measured in terms of obedience to Comintern policy; the wrangling among French party leaders over the Comintern instructions had doomed the elections from the start of the campaign. Only when the party leadership wholeheartedly supported the Comintern could the French party be truly victorious.

Humbert-Droz provided his prescription for the ills of the French party: "What is needed is a homogeneous majority [in the central committee]..." Maurice Thorez was brutally frank: "I desire the

1 Classe contre classe, Latin Secretariat, Sixth Comintern congress, Pierre Sémard, pp. 111-112. Nevertheless, Thorez believed that the "class against class" tactic had been successful. Thorez to Humbert-Droz, May 16, 1928 (HumbertDroz papers).

2 Humbert-Droz, "The French Elections and the Policy of the Communist Party", in: The Communist International (June 15, 1928), p. 277.

3 Ibid., pp. 277-279.

4 Ibid., p. 279.

5 Classe contre classe, Latin Secretariat, Sixth Comintern congress, HumbertDroz, p. 248. 
creation of a majority in the Political Bureau of comrades who have shown by their actions their agreement with the correct policy of the party and the Comintern."' The change desired by Thorez would not be produced overnight; two months after the Sixth Comintern congress he confided to Humbert-Droz that "...the Central Committee appears exactly as it is - an assembly that lies, and not an organ of leadership." 2 Moreover, Thorez was in a hurry to correct the situation. He was one of the men to whom Pierre Sémard referred when he wrote:

"During [the] struggles within and without the Party there have grown up within its ranks real leaders of the working-class movement, fighters who have learnt from experience in the factories, active in the Party and the trade unions, skilful in carrying on both legal and illegal work, steeled by government and employers' persecution.

It is this younger generation which is urging the Party forward along a Bolshevik path, which is to a greater and greater extent, taking the lead in its ranks...."3

At age 28 Maurice Thorez had examined himself and his party; he preferred to think of himself as a member of the Section française de l'internationale communiste instead of the Parti communiste français. And it was this attitude which would govern the French party's relationship to the Comintern and to the Soviet Union in the future.

1 Classe contre classe, Latin Secretariat, Sixth Comintern congress, Maurice Thorez, p. 186.

2 Thorez to Humbert-Droz, November 9, 1928 (Humbert-Droz papers).

${ }^{3}$ Pierre Sémard, "The Third International and the Working Class Movement in the Last Ten Years", in: The Communist International, VI, No 9-10 [1929], p. 418. 